\title{
The Effects of Metabolic Acidosis on Jejunal Phosphate and Glucose Transport in Weanling Rats
}

\author{
STEPHEN M. BOROWITZ, HAMID M. SAID, AND FAYEZ K. GHISHAN
}

Department of Pediatrics, Vanderbilt University Medical Center, Nashville, Tennessee 37232

\begin{abstract}
To investigate the effects of metabolic acidosis on jejunal phosphate and glucose absorption, in vivo and in vitro transport studies were performed on weanling rats fed $1.5 \% \mathrm{NH}_{4} \mathrm{Cl}$ for three days and on group pair-fed controls. Both in vivo and in vitro, acidosis significantly depressed phosphate transport without effecting glucose transport. In vitro, the decrease of phosphate transport was due to a depression of sodium-phosphate cotransport, but not of sodium independent phosphate transport. This corresponded to a significant increase of the $\mathrm{Km}$ of sodiumphosphate cotransport with no change of the Vmax. Treatment of the acidotic animals with intraperitoneal 1,25 dihydroxycholecalciferol did not restore phosphate transport to control levels. These studies indicate that in weanling rats, metabolic acidosis selectively suppresses jejunal phosphate transport independent of circulating levels of 1,25 dihydroxycholecalciferol. (Pediatr Res 20: 763-767, 1986)
\end{abstract}

Abbreviations
BBMV, brush border membrane vesicles
1,25(OH $)_{2} \mathrm{D}_{3}, 1,25$ dihydroxycholecalciferol

Phosphate transport across both the renal proximal tubule and the jejunum is an active process taking place against an electrochemical gradient, and inhibitable by arsenate $(1,2)$. Transport consists of a saturable, electroneutral sodium-dependent component, and a nonsaturable, sodium-independent component $(1,2)$. Both renal and jejunal phosphate transport decline during maturation $(3,4)$.

The normal skeleton is an important participant in the buffering of acid (5). During metabolic acidosis, skeletal hydrogen ion retention results in significant loss of trabecular bone $(6,7)$. Metabolic acidosis is also associated with phosphaturia independent of parathyroid hormone and dietary phosphate intake $(8,9)$. This phosphaturia appears to represent a direct inhibition of renal brush border membrane sodium-phosphate cotransport by metabolic acidosis (10).

The present studies were undertaken in an effort to determine whether metabolic acidosis affects jejunal phosphate transport in a manner similar to renal phosphate transport. Metabolic acidosis was acutely induced in weanling animals and jejunal phosphate and glucose transport were assessed both in vivo and in vitro.

Received January 27, 1986; accepted March 27, 1986.

Correspondence Stephen M. Borowitz, M.D., Division of Pediatric Gastroenterology, D-4I30 MCN, Vanderbilt University Medical Center, Nashville, TN 37232. This work was supported by NIH Research Grant RO1 AM 33209-01.

\section{MATERIALS AND METHODS}

Study design. Newborn litters of Sprague Dawley rats were obtained from Sasco Industries (Omaha, NE). Mothers were allowed free access to food and water, and the pups were allowed to suckle freely. At 17 days of age, litters were separated from the mothers and randomly divided into two groups. Group 1 (acidotic) was offered pulverized standard food to eat and $1.5 \%$ $\mathrm{NH}_{4} \mathrm{Cl}$ to drink. The animals were allowed free access to water and food. Group 2 (control) was pair fed as a group with the first group and offered water to drink ad libitum. After 3 days, arterial blood gases were obtained, and jejunal glucose and phosphate transport were measured in vivo and in vitro.

In vivo transport studies. In vivo transport was measured using a recirculating perfusion technique (11). Briefly, the proximal 20 $\mathrm{cm}$ of jejunum were cannulated with polyethylene inflow and outflow catheters and flushed with ice cold saline buffer and air. The intestinal segment was perfused at $0.1 \mathrm{ml} / \mathrm{min}$ with a solution consisting of $145 \mathrm{mM} \mathrm{NaCl}, 20 \mathrm{mM}$ Hepes/Tris (pH 6.5), and $0.1 \mathrm{mM}$ glucose labelled with ${ }^{3} \mathrm{H}$-glucose (specific activity $50 \mathrm{Ci} / \mathrm{mmol}$, New England Nuclear, Boston, MA), or $0.3 \mathrm{mM}$ $\mathrm{KH}_{2} \mathrm{PO}_{4}$ labeled with $\mathrm{KH}_{2}{ }^{32} \mathrm{PO}_{4}$ (specific activity $1 \mathrm{Ci} / \mathrm{mmol}$, New England Nuclear). After a 20-min equilibration period, duplicate $100-\mu 1$ aliquots were sampled every $10 \mathrm{~min}$ for $40 \mathrm{~min}$. The rate of glucose or phosphate absorption was calculated by determining the rate of disappearance of the solute from the perfusate. Fluid shifts were assessed using ${ }^{3} \mathrm{H}$ or ${ }^{14} \mathrm{C}$ labeled inulin as a nonabsorable marker (specific activity 0.5 and $50 \mathrm{Ci} / \mathrm{mol}$, respectively, New England Nuclear) and absorption was corrected for fluid shifts. ${ }^{3} \mathrm{H},{ }^{14} \mathrm{C}$, and ${ }^{32} \mathrm{P}$-labeled radioactivities were determined by double isotope counting and calculating techniques (12). Absorption results were expressed in terms of dry intestinal length since dry length correlates best with intestinal surface area (13).

In vitro transport studies. In vitro transport was measured using jejunal brush border membrane vesicles (14). Briefly, animals were anesthetized with ether and $0.4 \mathrm{ml}$ of blood was withdrawn from the abdominal aorta for arterial blood gas measurements. The entire jejunum was removed and washed with ice cold $0.9 \mathrm{~N}$ saline and everted over a glass rod. Brush border membrane vesicles were prepared by sequential precipitation with $0.01 \mathrm{M} \mathrm{MgCl}_{2}$ and differential centrifugation (15). The purity of the vesicle preparation for rats of varying ages has been previously demonstrated in our laboratory using morphologic criteria, enzymatic enrichment studies, and functional transport studies (15).

Glucose and phosphate uptakes were measured by a rapid filtration technique (16) using Sartorius cellulose nitrate filters of $0.45 \mu \mathrm{m}$ pore size (Sartorius Filters Inc., Hayward, CA) that had been presoaked in stop solution containing $100 \mathrm{mM}$ mannitol, $100 \mathrm{mM}$ choline chloride, $20 \mathrm{mM}$ hepes/tris, and $50 \mathrm{mM}$ magnesium chloride ( $\mathrm{pH}$ 7.4). Glucose stop solution also con- 
tained $0.2 \mathrm{mM}$ phlorizin. Incubations were carried out at room temperature using $\mathrm{KH}_{2}{ }^{32} \mathrm{PO}_{4}$ (specific activity $1 \mathrm{Ci} / \mathrm{mmol}$ ) or ${ }^{3} \mathrm{H}$-glucose (specific activity $50 \mathrm{Ci} / \mathrm{mmol}$ ) as a label (New England Nuclear). The composition of the incubation media for each individual experiment is described in the figure legends.

The protein content of the vesicle solution was determined by the method of Lowry et al. (17) using bovine serum albumin 1 $\mathrm{mg} / \mathrm{ml}$ as a standard.

Statistical methods. For the in vivo perfusion studies, all results presented are the mean \pm SEM of at least six observations in at least three animals. For the in vitro vesicle studies, all results presented are the mean \pm SEM of at least six observations from at least two separate vesicle preparations. Each vesicle preparation involved 10 to 12 suckling animals. $\mathrm{Km}$ and Vmax were determined according to a computer model for estimation of kinetic parameters (18). Data were analyzed using the Student's $t$ test and regression analysis.

\section{RESULTS}

After the 3-day feeding period, the animals drinking $\mathrm{NH}_{4} \mathrm{Cl}$ developed a significant metabolic acidosis as compared to the group drinking water (Table 1). The animals drinking $\mathrm{NH}_{4} \mathrm{Cl}$ had a mean arterial $\mathrm{pH}$ of 7.22 as compared to 7.46 in the control group $(p<0.05)$. Weights at the outset of the 3-day feeding period were identical in the two groups (Table 1). Despite being group pair fed, weight gain in the acidotic group was significantly less than in the control group $(p<0.05)$. Jejunal segments were examined in several of the acidotic animals and were found to be histologically normal.

In vivo perfusions. Table 2 depicts the absorption of $0.3 \mathrm{mM}$ phosphate in the acidotic and control animals. In both the control and acidotic animals, absorption of phosphate was linear throughout the $60-\mathrm{min}$ perfusions $(p<0.05)$. At each time point, phosphate uptake in the acidotic animals was significantly less than uptake in the control group $(p<0.05)$.

To determine whether the observed difference in phosphate transport between the two groups represented a general effect of metabolic acidosis on intestinal transport processes, or a specific effect on phosphate transport, the intestinal absorption of 0.1

Table 1. Weights and blood gas data in control and acidotic animals

\begin{tabular}{lll}
\hline & \multicolumn{3}{c}{ Control } & \multicolumn{1}{c}{ Acidotic } \\
\hline Initial wt $(\mathrm{g})$ & $29.3 \pm 1.7$ & $30.2 \pm 1.0$ \\
Final wt $(\mathrm{g})$ & $38.6 \pm 1.1$ & $33.2 \pm 1.0^{*}$ \\
Arterial pH & $7.46 \pm 0.04$ & $7.22 \pm 0.12^{*}$ \\
Serum $\mathrm{CO}_{2}(\mathrm{mmol} / \mathrm{liter})$ & $22.8 \pm 2.0$ & $10.6 \pm 3.5^{*}$ \\
$\mathrm{pCO}_{2}(\mathrm{~mm} \mathrm{Hg})$ & $31.0 \pm 6.5$ & $25.5 \pm 5.9$ \\
\hline
\end{tabular}

$* p<0.05$.
$\mathrm{mM}$ glucose was examined in the acidotic and control rats in a similar fashion (Table 2). In both the control and acidotic animals, absorption of glucose was linear throughout the 60min perfusions $(p<0.05)$. In contrast to phosphate absorption, glucose uptake in the control and acidotic animals was comparable at each time point.

In vitro transport. Effects of Acidosis upon Glucose and Phosphate Uptake by $B B M V$. To further define the effects of metabolic acidosis on jejunal phosphate and glucose transport, transport of glucose and phosphate was investigated using jejunal brush border membrane vesicles. Previous studies in our laboratory have demonstrated that both glucose and phosphate enter the intravesicular space with minimal binding to the vesicle membrane $(4,15)$.

To define the effects of sodium on phosphate uptake, jejunal brush border membrane vesicles from acidotic and control animals were prepared in a $\mathrm{Na}+-$ free buffer and incubated in either a Na+-containing buffer or a choline-containing buffer (Fig. 1). In vesicles from both groups of animals, phosphate uptake at 5 , $10,20,90$, and $300 \mathrm{~s}$ was significantly greater in the presence of $\mathrm{Na}+$ than in the presence of choline $(p<0.05)$. At $180 \mathrm{~min}$, phosphate uptake in the presence and absence of $\mathrm{Na}+$ was the same, indicating equilibrium had been reached. At all time points, phosphate uptake in the absence of $\mathrm{Na}+$ was comparable between the acidotic and control vesicles $(p>0.2)$. In contrast, at $5,10,20,90$, and $300 \mathrm{~s}$, phosphate uptake in the presence of $\mathrm{Na}+$ was significantly less in the vesicles prepared from acidotic animals as compared to vesicles prepared from controls $(p<$ 0.05 ).

Similar experiments were performed using $0.1 \mathrm{mM}$ glucose as a substrate (Fig. 2). In vesicles from both groups of animals, glucose uptake at $20 \mathrm{~s}$ and 1 and $2 \mathrm{~min}$ was significantly greater in the presence of $\mathrm{Na}+$ than in the presence of choline $(p<$ $0.05)$. Both groups of vesicles demonstrated a transient "overshoot" at $20 \mathrm{~s}$. At $60 \mathrm{~min}$, glucose uptake in the presence and absence of $\mathrm{Na}+$ was the same, indicating equilibrium had been reached. In contrast to phosphate, glucose uptake both in the presence and absence of $\mathrm{Na}+$ was the same in vesicles prepared from acidotic and control animals $(p>0.2)$.

Effect of Acidosis on Kinetics of Phosphate Uptake by BBMV. In an effort to determine the kinetics of sodium-dependent phosphate transport, vesicles from acidotic and control animals were incubated in a $\mathrm{Na}+$ containing buffer with phosphate concentration varying from 0.01 to $1.0 \mathrm{mM}$ (Fig. 3). Uptake was measured at $10 \mathrm{~s}$, during the linear phase of uptake $(1,19)$. Both in the presence and absence of $\mathrm{Na}+$, phosphate uptake increased as the concentration of phosphate in the media was increased. The active component of phosphate uptake can be considered the difference of sodium-dependent uptake and sodium-independent uptake. In both groups, the active component of phosphate uptake was described by a rectangular hyperbola. Table 3 depicts kinetic data for active phosphate uptake in acidotic and

Table 2. Effect of metabolic acidosis on in vivo jejunal phosphate and glucose absorption*

Phosphate absorption (nmol/100

cm dry length) after perfusion

for:

\begin{tabular}{lllll} 
& $10 \mathrm{~min}$ & \multicolumn{1}{c}{$20 \mathrm{~min}$} & \multicolumn{1}{c}{$30 \mathrm{~min}$} & \multicolumn{1}{c}{$40 \mathrm{~min}$} \\
\hline Control & $1.35 \pm 0.2$ & $1.97 \pm 0.3$ & $2.83 \pm 0.5$ & $3.47 \pm 0.2$ \\
Acidotic & $0.63 \pm 0.2 \dagger$ & $1.17 \pm 0.2 \dagger$ & $1.95 \pm 0.1 \dagger$ & $2.88 \pm 0.2 \dagger$
\end{tabular}

Glucose absorption $(\mathrm{nmol} / 100 \mathrm{~cm}$

dry length) after perfusion for:

\begin{tabular}{lcccc} 
& $10 \mathrm{~min}$ & $20 \mathrm{~min}$ & $30 \mathrm{~min}$ & $40 \mathrm{~min}$ \\
\hline Control & $19.0 \pm 0.5$ & $43.4 \pm 3.9$ & $66.4 \pm 8.8$ & $88.4 \pm 10.1$ \\
Acidotic & $18.9 \pm 2.8$ & $38.5 \pm 5.1$ & $62.7 \pm 4.7$ & $84.8 \pm 5.9$ \\
\hline
\end{tabular}

* Twenty cm of jejunum were perfused for $40 \mathrm{~min}$ with buffer $\mathrm{pH}(6.5)$ containing $0.3 \mathrm{mM} \mathrm{KH}_{2} \mathrm{PO}_{4}$ or $0.1 \mathrm{mM} d$-glucose.

$\dagger p<0.05$. 

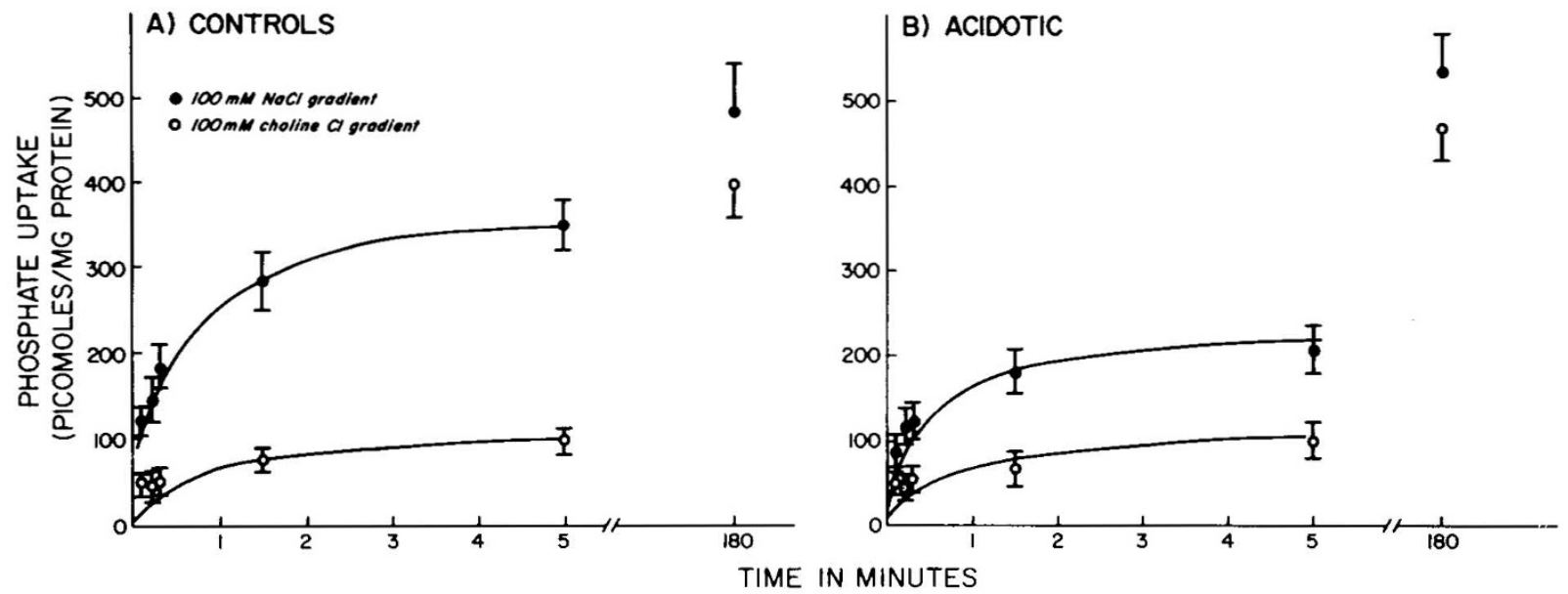

Fig. 1. Phosphate uptake into jejunal brush border membrane vesicles: effects of a sodium gradient. Jejunal brush border membrane vesicles from 21-day-old control rats $(A)$ and acidotic rats $(B)$ were loaded with a buffer containing $0.1 \mathrm{M}$ mannitol, $0.1 \mathrm{M}$ choline chloride, and $20 \mathrm{mM}$ Hepes/Tris ( $\mathrm{pH}$ 7.4). The vesicles were incubated at room temperature in a medium containing $0.1 \mathrm{mM}$ phosphate, $0.1 \mathrm{M}$ mannitol, $20 \mathrm{mM}$ Hepes/ Tris ( $\mathrm{pH}$ 7.4), $0.1 \mathrm{M} \mathrm{NaCl}(\bullet)$ or $0.1 \mathrm{M}$ choline $\mathrm{Cl}(\mathrm{O})$. Phosphate uptake is expressed as $\mathrm{pmol} / \mathrm{mg}$ of vesicle protein.
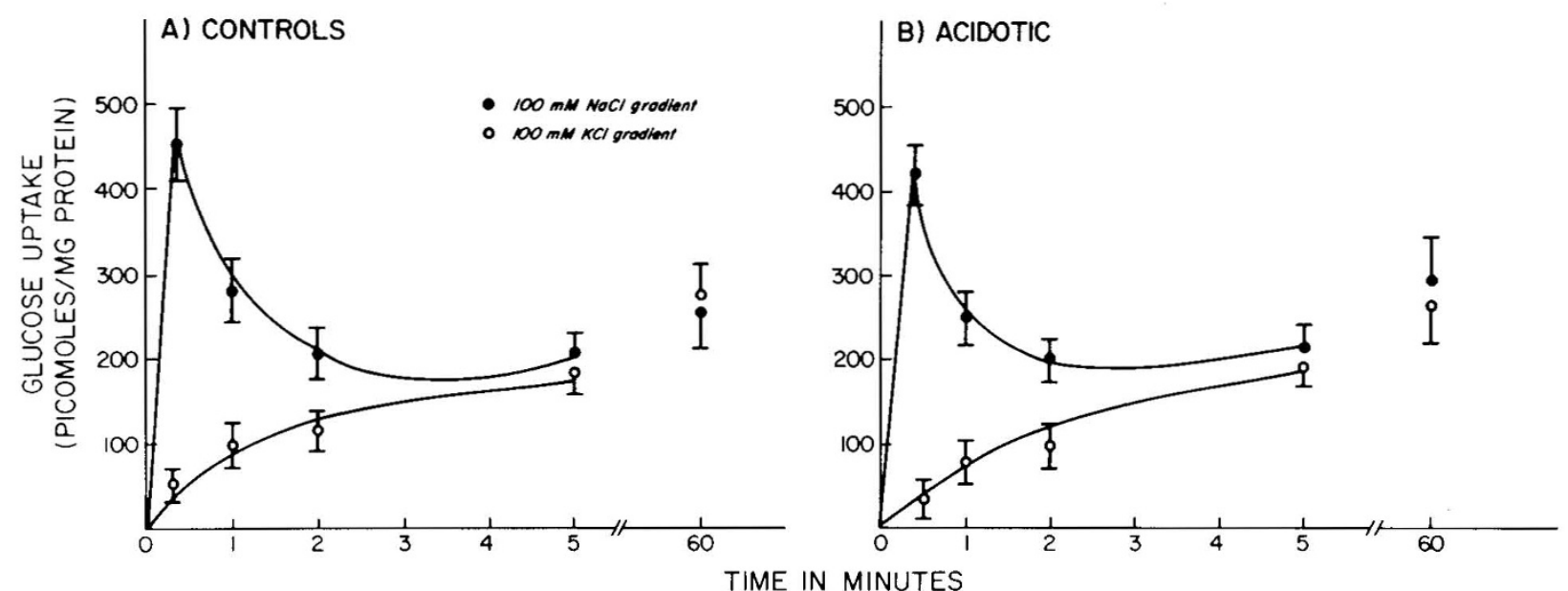

Fig. 2. Glucose uptake into jejunal brush border membrane vesicles: effects of metabolic acidosis. Jejunal brush border membrane vesicles from 21 -day-old control rats $(A)$ and acidotic rats $(B)$ were loaded with a buffer containing $0.1 \mathrm{M}$ mannitol, $0.1 \mathrm{M}$ choline chloride, and $20 \mathrm{mM}$ Hepes/ Tris ( $\mathrm{pH}$ 7.4). The vesicles were incubated at $37^{\circ} \mathrm{C}$ in a medium containing $0.1 \mathrm{mM}$ d-glucose $0.1 \mathrm{M}$ mannitol, $20 \mathrm{mM} \mathrm{Hepes/Tris} \mathrm{(pH} \mathrm{7.4),} 0.1 \mathrm{M}$ $\mathrm{NaCl}(\bullet)$, or $0.1 \mathrm{M} \mathrm{KCl}(0)$. Glucose uptake is expressed as pmol/mg of vesicle protein.
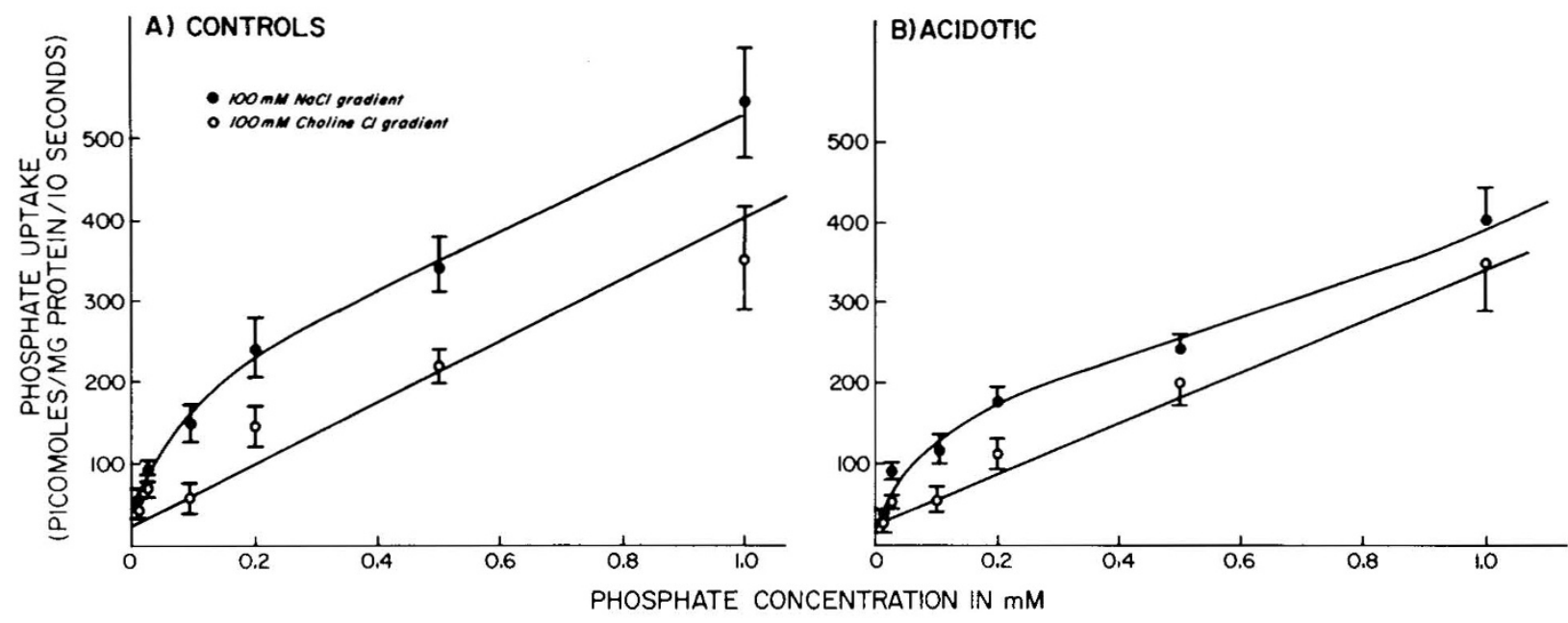

Fig. 3. Phosphate uptake into jejunal brush border membrane vesicles: effects of phosphate concentration. Jejunal brush border membrane vesicles from 21-day-old control rats $(A)$ and acidotic rats $(B)$ were loaded with a buffer containing $0.1 \mathrm{M}$ mannitol, $0.1 \mathrm{M}$ choline chloride, and 20 $\mathrm{mM}$ Hepes/Tris ( $\mathrm{pH}$ 7.4). The vesicles were incubated with increasing phosphate concentrations in $0.1 \mathrm{M}$ mannitol, $20 \mathrm{mM}$ Hepes/Tris (pH 7.4), and $0.1 \mathrm{M} \mathrm{NaCl}(\bullet)$ or $0.1 \mathrm{M}$ Choline $\mathrm{Cl}(\bigcirc)$. Uptake was measured at $10 \mathrm{~s}$. 
control animals. As seen, Vmax values were similar in both the acidotic and control animals, however, $\mathrm{Km}$ for the acidotic group was significantly greater than the corresponding value for the controls $(p<0.05)$.

Effect of $1,25(\mathrm{OH})_{2} D_{3}$ on Phosphate Uptake into $B B M V$ from Acidotic Animals. To determine whether the observed differences in phosphate uptake between the vesicles from the acidotic and control animals were due to inadequate circulating levels of $1,25(\mathrm{OH})_{2} \mathrm{D}_{3}$, acidotic animals were injected intraperitoneally with $1 \mu \mathrm{g}$ of $1,25(\mathrm{OH})_{2} \mathrm{D}_{3}$ (Hoffman-LaRoche, Nuxley, NJ) 48 and $24 \mathrm{~h}$ prior to sacrifice. Phosphate uptake was measured as before in the presence and absence of Na+ (Fig. 4). Both Natindependent and $\mathrm{Na}+$-dependent phosphate uptake tended to be lower in the injected group than in the uninjected group, however, the differences were not statistically different $(p>0.1)$.

\section{DISCUSSION}

The results of these studies indicate that metabolic acidosis induced by the feeding of $\mathrm{NH}_{4} \mathrm{Cl}$ impairs jejunal phosphate absorption in weanling rats both in vivo and in vitro. Glucose absorption is unaffected by metabolic acidosis suggesting that observed changes in phosphate transport do not represent generalized effects on intestinal transport processes. The depression of phosphate transport is due to inhibition of sodium coupled phosphate cotransport. Passive phosphate uptake is unaffected by acidosis. Kinetic analysis indicates the suppression of phosphate transport is due to a change in the $\mathrm{Km}$ but not the Vmax of sodium phosphate contransport. This reflects a change in the affinity of the sodium-phosphate cotransporter for phosphate without effecting the number or activity of the transporters.

It is unlikely that differences in the brush border membrane

Table 3. Kinetics of phosphate uptake in BBMV from control and acidotic rats

\begin{tabular}{lrl}
\hline & Control & Acidotic \\
\hline Km (mM phosphate) & $0.059 \pm 0.06$ & $0.37 \pm 0.02^{*}$ \\
Vmax (pmol phosphate/ & $96.9 \pm 1.02$ & $98.9 \pm 1.81$ \\
mg protein/10 s) & & \\
\hline
\end{tabular}

$* p<0.05$.

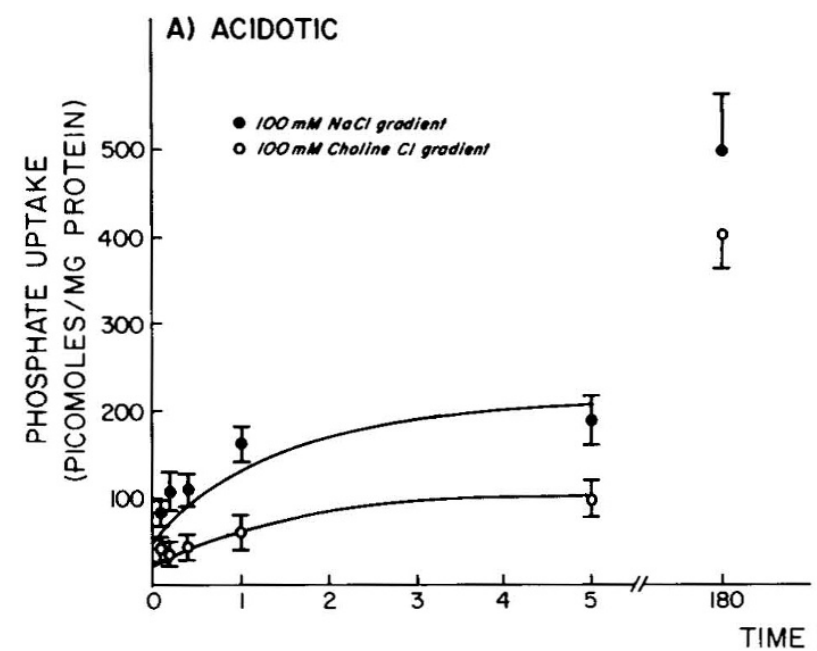

vesicle preparations from acidotic and control animals account for the observed differences in phosphate transport in the two groups in that glucose uptake was identical in both groups. Moreover, at equilibrium, glucose and phosphate uptakes were the same in vesicles from control and acidotic animals, indicating similar intravesicular size in the two groups. It appears that the depression of phosphate transport observed in the acidotic animals represents a selective depression of sodium-phosphate cotransport by acidosis.

In adult animals, $1,25(\mathrm{OH})_{2} \mathrm{D}_{3}$ is the most biologically active metabolite of vitamin $\mathrm{D}$. The literature describing the effects of metabolic acidosis on vitamin D homeostasis is conflicting. Acidosis inhibits the production of $1,25(\mathrm{OH})_{2} \mathrm{D}_{3}$ by suppressing renal 1- $\alpha$-hydroxylase activity in chicks and rats raised on vitamin $\mathrm{D}$-deficient diets and supplied with exogenous vitamin $\mathrm{D}_{3}(20-25)$, however, this suppression of hydroxylase activity is attenuated with prolonged acidosis (26). In vitamin D-replete rats, serum $1,25(\mathrm{OH})_{2} \mathrm{D}_{3}$ levels are either normal or elevated and rise in response to calcium and phosphate restriction $(27,28)$. $1,25(\mathrm{OH})_{2} \mathrm{D}_{3}$ exerts its effects on jejunal phosphate absorption by enhancing the $\mathrm{Na}+$-dependent component of phosphate transport. This is reflected in a change of the Vmax of the sodium-phosphate cotransport system with no effect on the $\mathrm{Km}$ (29-31). This is in contrast to the effects of acidosis observed in this study which demonstrated a change in the $\mathrm{Km}$ of sodiumphosphate cotransport with no change of the Vmax. While serum levels of the vitamin D metabolites were not measured in this study, intraperitoneal injection of the acidotic animals with pharmacologic doses of $1,25(\mathrm{OH})_{2} \mathrm{D}_{3}$ did not restore phosphate transport to control levels, providing indirect evidence that the suppression of intestinal phosphate transport by metabolic acidosis is not mediated by changes in vitamin D homeostasis.

Phosphate transport across the renal proximal tubule is very similar to transport of phosphate across the jejunal brush border. Both systems consist of sodium-dependent and sodium-independent components $(1,2)$. In vitamin D-replete adult rats, fasting depresses brush border sodium-phosphate cotransport and increases urinary phosphate excretion. This is associated with an increase in the $\mathrm{Km}$ of the brush border phosphate transport system but no change in the Vmax (32). While the acidotic animals in the current study weighed less than the controls, food intake was equivalent, indicating protein calorie

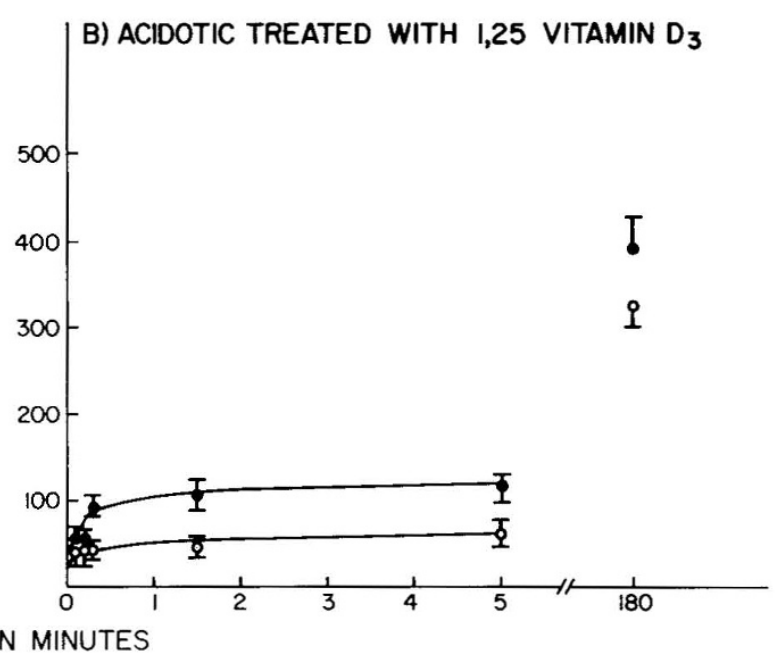

Fig. 4. Phosphate uptake into jejunal brush border membrane vesicles from acidotic rats: effects of $1,25(\mathrm{OH})_{2}$ vitamin $\mathrm{D}_{3}$. Jejunal brush border membrane vesicles from 21-day-old acidotic rats were loaded with a buffer containing $0.1 \mathrm{M}$ mannitol, $0.1 \mathrm{M}$ choline chloride, and $20 \mathrm{mM}$ Hepes/ Tris ( $\mathrm{pH}$ 7.4). The vesicles were incubated at room temperature in a medium containing $0.1 \mathrm{mM}$ phosphate, $0.1 \mathrm{M}$ mannitol, $20 \mathrm{mM}$ hepes/tris (pH 7.4), and $0.1 \mathrm{M} \mathrm{NaCl}(\bullet)$ or $0.1 \mathrm{M}$ Choline $\mathrm{Cl}(O)$. Vesicles depicted in $A$ on the left were prepared from animals receiving no supplemental vitamin $\mathrm{D}$. Vesicles depicted in $B$ on the right were prepared from animals receiving $1 \mu \mathrm{g}$ of intraperitoneal $1,25(\mathrm{OH})_{2}$ vitamin $\mathrm{D}_{3} 48$ and $24 \mathrm{~h}$ prior to sacrifice. 
restriction does not account for the observed differences in the two groups. Moreover, while effects of fasting on jejunal phosphate transport in weanling animals are unknown, glucose transport increases during protein calorie restriction in young animals (33). The failure of glucose transport to increase significantly in the acidotic animals provides additional evidence that proteincalorie malnutrition did not cause the observed suppression of phosphate transport.

Administration of glucocorticoids depresses renal phosphate reabsorption independent of parathormone release or serum phosphate concentration $(34,35)$. This phosphaturia appears due to the selective depression of sodium-dependent phosphate transport; sodium-independent phosphate uptake is not altered (36). Glucocorticoid therapy does not alter sodium-dependent or sodium-independent glucose uptake (37) suggesting glucocorticoid therapy does not depress all forms of sodium coupled transport in the kidney.

The effects of glucocorticoids on the intestinal absorption of phosphate are not well established. In experimental animals and in man, glucocorticoid therapy has been reported to depress phosphate absorption $(38,39)$. The premature weaning of rats is associated with a surge of glucocorticoid release (40), and we have observed that the premature weaning of rats is associated with a decline in jejunal phosphate transport by brush border membrane vesicles (Borowitz SM, Ghishan FK, unpublished observation). Metabolic acidosis constitutes a significant stress and is likely associated with glucocorticoid release, which may mediate the observed depression of phosphate transport observed in the acidotic animals. The failure of acidosis to induce changes in jejunal glucose transport may be explained by the fact that glucocorticoids do not alter jejunal glucose absorption in suckling animals (41)

In conclusion, in weanling rats, metabolic acidosis induced by drinking $\mathrm{NH}_{4} \mathrm{Cl}$ for 3 days depresses sodium-coupled jejunal phosphate transport by affecting the $\mathrm{Km}$ but not the Vmax of sodium-phosphate cotransport. The observed changes in phosphate transport do not reflect a generalized effect of acidosis on intestinal transport in that glucose transport is unaffected and do not appear to be related to changes in the circulating level of $1,25(\mathrm{OH})_{2} \mathrm{D}_{3}$ in that injection of pharmacologic doses of the vitamin do not restore phosphate transport to control levels. The etiology of the depression of sodium-phosphate cotransport by metabolic acidosis is unclear. We speculate that the stress of acidosis may cause a surge of glucocorticoid release which depresses sodium-coupled phosphate transport.

\section{REFERENCES}

1. Berner WR, Kinne R, Murer H 1976 Phosphate transport into brush border membrane vesicles isolated from rat small intestine. Biochem $\mathbf{J}$ 160:467474

2. Cheng L, Sacktor B 1981 Sodium gradient-dependent phosphate transport in renal brush border membrane vesicles. J Biol Chem 256:1556-1564

3. Caverzasio J, Murer H, Fleisch H, Bonjour JP 1982 Phosphate transport in brush border membrane vesicles isolated from renal cortex of young growing and adult rats. Pflugers Arch 394:217-221

4. Borowtiz SB, Ghishan FK 1985 Maturation of jejunal phosphate transport by brush border membrane vesicles. Pediatr Res 19:1308-1312

5. Bushinsky D, Krieger N, Geisser D, Grossman E, Coe F 1983 Effects of pH on bone calcium and proton fluxes in vitro. Am J Physiol 245:F204-F209

6. Chan YL, Savdie E, Mason RS, Posen S 1985 The effect of metabolic acidosis on vitamin $\mathrm{D}$ metabolites and bone histology in uremic rats. Calcif Tissue Int 37:158-164

7. Barzel US, Jowsey J 1969 The effects of chronic acid and alkali administration on bone turnover in adult rats. Clin Sci 36:517-524

8. Beck N, Webster SK, Reineck HJ 1979 Effect of fasting on tubular phosphate reabsorption. Am J Physiol 237:F241-F246

9. Guntupalli J, Eby B, Lau K 1981 On the phosphaturia produced by $\mathrm{NH}_{4} \mathrm{C}$ administration: interaction with $\mathrm{PTH}$ and diet $\mathrm{PO}_{4}$ : evidence for the role of acidemia. Kidney Int 19:111-115

10. Levine BS, Jo K, Kraut JA, Coburn JW, Kurokawa K 1983 Effect of metabolic acidosis on phosphate transport by the renal brush border membrane. Biochem Biophys Acta 727:7-12

11. Said HM, Hollander DH, Katz D 1984 Absorption of 5-methyltetrahydrofolate in rat jejunum with intact blood and lymphatic vessles. Bioch Biophy Acta 775:402-408

12. Kobayashi Y, Maudsley DV 1970 In: Bransome E, Grune S (eds) Liquid Scintillation Counting. New York, Academic Press, pp 76-85

13. Westergarred $H$, Dietschy J 1974 Delineation of the dimensions and permeability characteristics of the two major diffusional barriers to passive mucosal uptake in the rabbit intestine. J Clin Invest 54:718-732

14. Murer H, Kinne R 1980 The use of isolated membrane vesicles to study epithelial transport processes. J Membrane Biol 55:81-95

15. Ghishan $\mathrm{F}$, Wilson $\mathrm{F} 1985$ Developmental maturation of $d$-glucose transport by rat jejunal brush-border membrane vesicles. Am J Physiol 248:G87-G92

16. Hopfer U, Nelson K, Penotto J, Isselbacker KJ 1973 Glucose transport in isolated brush border membrane from rat small intestine. J Biol Chem 248:25-32

17. Lowry DH, Rosebrough NJ, Farr AL, Randall RJ 1951 Protein measurement with the folin phenol reagent. J Biol Chem 193:265-275

18. Vaughn WK, Neal RA, Anderson AJ 1976 Computer estimation of the parameters of the sigmoid kinetic model. Comput Biol Med 6:1-7

19. Danisi G, Murer H, Straub RW 1984 Effect of $\mathrm{pH}$ on phosphate transport into intestinal brush-border membrane vesicles. Am J Physiol 246:G180-G186

20. Lee SW, Russell J, Avioli LV 1977 25-hydroxycholecalciferol to 1,25-dihydroxycholecalciferol: conversion impaired by systemic metabolic acidosis. Science 195:994-997

21. Bikle DD, Rasmussen $H 1975$ The ionic control of 1,25-dihydroxyvitamin $\mathrm{D}_{3}$ production in isolated chick renal tubules. J Clin Invest 55:292-298

22. Sauveur B, Garabedian M, Fellot C, Mongin P, Balsan S 1977 The effect of induced metabolic acidosis on vitamin $\mathrm{D}_{3}$ metabolism in rachitic chicks. Calcif Tissue Res 23:121-124

23. Baran DT, Lee SW, Jo OD, Avioli LV 1982 Acquired alterations in vitamin D metabolism in the acidotic state. Calcif Tissue Int 34:165-168

24. Reddy GS, Jones G, Kooh SW, Fraser D 1982 Inhibition of 25-hydroxyvitamin $\mathrm{D}_{3}$-1-hydroxylase by chronic metabolic acidosis. Am J Physiol 243:E265E271

25. Kawashima H, Kraut JA, Kurokawa K 1982 Metabolic acidosis suppresses 25-hydroxyvitamin $\mathrm{D}_{3}-1$-alpha-hydroxylase in the rat kidney. J Clin Invest 70:135-140

26. Cunningham J, Bikle DD, Avioli LV 1984 Acute but not chronic, metabolic acidosis disturbs 25-hydroxyvitamin $\mathrm{D}_{3}$ metabolism. Kidney Int 25:47-52

27. Gafter U, Kraut JA, Lee DB, Silis V, Walling MW, Kurokawa K, Haussler MR, Coburn JW 1980 Effect of metabolic acidosis on intestinal absorption of calcium and phosphorus. Am J Physiol 229:G480-G484

28. Bushinsky DA, Favus MJ, Schneider AB, Sen PK, Sherwood LM, Coe FL 1982 Effects of metabolic acidosis on PTH and $1,25(\mathrm{OH})_{2} \mathrm{D}_{3}$ response to low calcium diet. Am J Physiol 243:F570-F575

29. Danisi G, Bonjour JP, Straub RW 1980 Regulation of Na-dependent phosphate influx across the mucosal border of duodenum by 1,25 -dihydroxycholecalciferol. Pflugers Arch 388:227-232

30. Fuchs R, Peterlik M 1980 Vitamin D-induced phosphate transport in intestinal brush border membrane vesicles. Bioch Biophys Res Commun 93:87-92

31. Hildmann B, Storelli, Danisi G, Murer H 1982 Regulation of Nat-Pi cotransport by 1,25-dihydroxyvitamin $\mathrm{D}_{3}$ in rabbit dudoenal brush-border membrane. Am J Physiol 242:G533-G539

32. Kempson SA 1985 Effects of fasting compared to low phosphorus diet on the kinetics of phosphate transport by renal brush-border membranes. Bioch Biophys Acta 815:85-90

33. Younoszai MK, Lynch A 1974 In vivo intestinal absorption of hexose intestinal absorption of hexose in growth-retarded suckling rat pups. J Nutr 104:671 677

34. Czekalski S, Knox FG, Dousa TP 1982 Restoration of phosphaturic response to parathyroid hormone by glucocorticoid treatment in phosphorus-deprived rats. J Lab Clin Med 100:858-865

35. Frick A, Durasin I, Neuweg M 1981 Phosphaturic response of hydrocortisone in the presence and absence of parathyroid hormone. Pflugers Arch 392:99105

36. Turner ST, Kiebzak GM, Dousa TP 1982 Mechanism of glucocorticoid effect on renal transport of phosphate. Am J Physiol 243:C227-C236

37. Freiberg JM, Kinsella J, Sacktor B 1982 Glucocorticoids increase the Na+-H+ exchange and decrease the $\mathrm{Na}+$ gradient-dependent phosphate-uptake systems in renal brush border membrane vesicles. Proc Natl Acad Sci USA 79:4932-4936

38. Ferraro C, Ladizesky M, Cabrejas M, Montoreano R, Mautalen C 1980 Intestinal absorption of phosphate: action of protein synthesis inhibitors and glucocorticoids in the rat. J Nutr 106:1752-1758

39. Walker GS, Peacock M, Marshall D, Giles RS, Davison AM 1980 Factors influencing the intestinal absorption of calcium and phosphorus following renal transplantation. Nephron 26:225-232

40. Henning SJ 1985 Ontogeny of enzymes in the small intestine. Ann Rev Physiol 47:231-245

41. Meneely R, Ghishan FK 1982 Intestinal maturation in the rat: the effect of glucocorticoids on sodium, potassium, water and glucose absorption. Pediatr Res 16:776-778 